\title{
Dental Plaque as a Microbial Biofilm
}

\author{
P.D. Marsh \\ Leeds Dental Institute and Health Protection Agency, Porton Down, Salisbury, UK
}

\section{Key Words}

Biofilm · Antimicrobial agents · Antimicrobial resistance $\cdot$ Gene transfer $\cdot$ Gene expression - Cell

signalling . Dental plaque species. A greater understanding of the significance of dental plaque as a mixed culture biofilm will lead to novel control strategies.

Copyright $@ 2004$ S. Karger AG, Basel

\begin{abstract}
New technologies have provided novel insights into how dental plaque functions as a biofilm. Confocal microscopy has confirmed that plaque has an open architecture similar to other biofilms, with channels and voids. Gradients develop in areas of dense biomass over short distances in key parameters that influence microbial growth and distribution. Bacteria exhibit an altered pattern of gene expression either as a direct result of being on a surface or indirectly as a response to the local environmental heterogeneity within the biofilm. Bacteria communicate via small diffusible signalling molecules (e.g. competence-stimulating peptide, CSP; autoinducer 2); CSP induces both genetic competence and acid tolerance in recipient sessile cells. Thus, rates of gene transfer increase in biofilm communities, and this is one of several mechanisms (others include: diffusion-reaction, neutralization/inactivation, slow growth rates, novel phenotype) that contribute to the increased antimicrobial resistance exhibited by bacteria in biofilms. Oral bacteria in plaque do not exist as independent entities but function as a co-ordinated, spatially organized and fully metabolically integrated microbial community, the properties of which are greater than the sum of the component
\end{abstract}

\section{KARGER}

Fax + 41613061234

E-Mail karger@karger.ch

www. karger.com
(C) 2004 S. Karger AG, Basel

0008-6568/04/0383-0204\$21.00/0

Accessible online at: www. karger.com/cre
Dental plaque can be defined as the diverse community of micro-organisms found on the tooth surface as a biofilm, embedded in an extracellular matrix of polymers of host and microbial origin. There is a high level of interest in the properties of biofilms and microbial communities across all sectors of industrial, environmental and medical microbiology [Allison et al., 2000]. This is because biofilms express properties not exhibited by the same organisms growing in liquid (planktonic) culture, while bacteria are invariably found in nature as part of a consortium, the properties of which are more than the sum of the component species. This review will focus on the significance to oral bacteria of their adoption of a biofilm and microbial community lifestyle, and highlight areas of current controversy and research activity.

\section{Dental Plaque - Existing Perspective}

Research over several decades has provided a solid foundation for current studies of oral biofilms. Numerous cultural studies have reported the diversity of the resident oral microflora, both at the genus and species level in health and disease [Newman and Wilson, 1999]. The
Prof. P.D. Marsh

Health Protection Agency Porton Down

Centre for Applied Microbiology \& Research

Salisbury, SP4 0JG (UK)

Tel. +44 1980 612287, Fax +44 1980 612731, E-Mail phil.marsh@hpa.org.uk 
development of dental plaque has been described in detail (a) on a clean surface over time, (b) in people of different ages, from different countries and diets, and with precise deficiencies in their host defences (acquired and innate), and (c) following various therapies [Percival et al., 1991; Nyvad, 1993; Marsh, 2000a]. The composition of dental plaque also varies on distinct anatomical surfaces (e.g. fissures, approximal and smooth surfaces, gingival crevice, dentures) due to the prevailing physical and biological properties of each site [Bowden et al., 1975; Slots, 1977; Theilade et al., 1982]. Recognition of these environmental influences on plaque composition has led to concepts on disease prevention that have embraced ecological principles [Marsh, 2003].

Dental plaque accumulates preferentially at stagnant sites that afford protection from the vigorous removal forces that apply in the mouth. Distinct phases of development can be recognized, including:

(a) Adsorption of host and bacterial molecules to the tooth surface. This conditioning film (the acquired pellicle) forms immediately following eruption or cleaning [AlHashimi and Levine, 1989] and directly influences the pattern of initial microbial colonization. Modern techniques offer the opportunity to more fully explore the distribution and composition of pellicle components [Li et al., 2003]. The conformational changes that may occur following adsorption of molecules, and the impact of this on their properties, are now amenable for study: for example, the molecular structure of glucans changes when glucosyltransferases are adsorbed to a surface [Vacca-Smith et al., 1996; Kopec et al., 2001].

(b) Passive transport of oral bacteria to the tooth surface. Weak, long-range physicochemical interactions between the microbial cell surface and the pellicle-coated tooth create a weak area of net attraction that facilitates reversible adhesion [Busscher and van der Mei, 1997]. Subsequently, strong, short-range interactions between specific molecules on the bacterial cell surface (adhesins) and complementary receptors in the pellicle can result in irreversible attachment [Jenkinson and Lamont, 1997; Lamont and Jenkinson, 2000] and can explain microbial tropisms for surfaces. Oral bacteria generally possess more than one type of adhesin on their cell surface and can participate in multiple interactions both with host molecules and similar receptors on other bacteria (coadhesion).

(c) Co-adhesion of later colonizers to already attached early colonizers. This stage also involves specific interbacterial adhesin-receptor interactions (often involving lectins) and leads to an increase in the diversity of the bio- film and to the formation of unusual morphological structures, such as corn-cobs and rosettes [Kolenbrander et al., 2000]. Co-adhesion may also facilitate the functional organization of dental plaque. Bacteria engage in a range of antagonistic and synergistic biochemical interactions [Marsh and Bradshaw, 1999]. The efficiency of metabolic interactions among bacteria in food chains may be enhanced if they are brought into close physical contact. Likewise, the co-adhesion of obligately anaerobic bacteria to oxygen-consuming species can ensure their survival in overtly aerobic oral environments [Bradshaw et al., 1998].

(d) Multiplication of the attached micro-organisms. Cell division leads to confluent growth and, eventually, a three-dimensional spatially and functionally organized, mixed-culture biofilm. Polymer production results in the formation of a complex extracellular matrix made up of soluble and insoluble glucans, fructans and heteropolymers. Such a matrix is a common feature of biofilms and makes a significant contribution to the known structural integrity and general resistance of biofilms; the matrix can be biologically active and retain nutrients, water and key enzymes within the biofilm [Allison, 2003]. Further studies are required to fully understand the influence of the matrix on the architecture and properties of dental plaque. When viewed by conventional light or electron microscopy, mature dental plaque appears as a densely packed structure [Listgarten, 1999; Marsh and Nyvad, 2003]; however, the recent application of novel microscopic techniques has demonstrated a more open architecture (see later). Endogenous substrates (derived from saliva or gingival crevicular fluid) are the main source of nutrients for oral bacteria [Beighton et al., 1986], but their catabolism requires the concerted and sequential action of groups of microbes with complementary enzyme profiles [Bradshaw et al., 1994; Marsh and Bowden, 2000], i.e. plaque functions as a true microbial community.

(e) Active detachment. Bacteria can respond to environmental cues and detach from surfaces, enabling cells to colonize elsewhere. For example, enzymes produced by sessile bacteria can hydrolyse the specific adhesins that anchor cells to the surface [Cavedon and London, 1993; Lee et al., 1996].

Once established, the resident plaque microflora remains relatively stable over time and is of benefit to the host [Marsh, 2000b]. The resident microflora of all sites plays a critical role in the normal development of the physiology of the host and also reduces the chance of infection by acting as a barrier to colonization by exogenous (and often pathogenic) species ('colonization resis- 
Table 1. General properties of biofilms and microbial communities

\begin{tabular}{ll}
\hline General property & Dental plaque example \\
\hline Open architecture & Presence of channels and voids \\
Protection from host defences, desiccation etc. & Production of extracellular polymers to form a functional matrix \\
Enhanced resistance to antimicrobials & Increased resistance to chlorhexidine and antibiotics \\
Neutralization of inhibitors & $\beta$-Lactamase production by neighbouring cells to protect sensitive organisms \\
Novel gene expression & Synthesis of novel proteins; up-regulation of $g t f B C$ \\
Co-ordinated gene responses & Production of cell-cell signalling molecules (e.g. CSP, autoinducer 2) \\
Spatial and environmental heterogeneity & pH and $\mathrm{O}_{2}$ gradients; co-adhesion \\
Broader habitat range & Obligate anaerobes in an overtly aerobic environment \\
More efficient metabolism & Complete catabolism of complex host macromolecules (e.g. mucins) by consortia \\
\end{tabular}

tance') [McFarland, 2000]. Mechanisms contributing to colonization resistance include more effective competition for nutrients and attachment sites, the production of inhibitory factors and creation of unfavourable growth conditions by the resident microflora. Thus, treatment should attempt to control rather than eliminate the plaque microflora.

\section{Dental Plaque - Paradigm Shifts}

Novel non-invasive and non-destructive microscopic techniques, the publication of annotated microbial genomes (which has facilitated new fields such as functional and comparative genomics, transcriptomics and proteomics), the development of molecular tools (e.g. reporter systems to determine gene activity, oligonucleotide probes to identify and locate specific bacteria via PCR or fluorescent in situ hybridization) combined with laboratory and in vivo biofilm models are changing our understanding of the biology of dental plaque (table 1). Selected topics of current research activity are highlighted below.

\section{Structure of Dental Plaque}

Confocal laser scanning microscopy has confirmed that supragingival plaque has a more open architecture (similar to that of biofilms from other habitats) than was suggested by the earlier electron microscopy reports, with channels traversing from the outside of the biofilm to the enamel surface [Wood et al., 2000; Auschill et al., 2001; Zaura-Arite et al., 2001]. Live/dead stains have suggested that bacterial vitality may vary throughout the biofilm, with the most viable bacteria present in the central part of plaque, and lining the voids and channels [Auschill et al.,
2001], although the fidelity of such stains for viable/nonviable cells is not 100\% [Gelle et al., 2003; Hope and Wilson, 2003]. This more open architecture, combined with the synthesis of a matrix comprised of a diverse range of exopolymers, creates a complex environment for predicting the penetration and distribution of molecules within plaque. Uneven patterns of penetration of radiolabelled fluoride, sucrose and phosphate were found in plaque generated naturally on an in situ biofilm model in volunteers [Robinson et al., 1997], while the diffusion of glucans of increasing molecular size was retarded in laboratory mixed culture biofilms [Thurnheer et al., 2003]. Bacterial metabolism ensures that gradients develop in parameters that are critical to microbial growth (nutrients, $\mathrm{pH}$, oxygen); the gradients in $\mathrm{pH}$ are also responsible for enamel demineralization. These gradients are not necessarily linear; the use of two-photon excitation microscopy coupled with fluorescent life-time imaging demonstrated considerable heterogeneity in $\mathrm{pH}$ over relatively short distances [Vroom et al., 1999]. Such environmental heterogeneity enables micro-organisms to co-exist in plaque biofilms that would be incompatible with one another in a homogeneous environment; this explains how organisms with contradictory metabolic requirements (e.g. in terms of atmosphere, nutrition) persist at the same site.

\section{Bacterial Composition of Dental Plaque}

Approximately $50 \%$ of cells in plaque (especially from subgingival sites) cannot as yet be cultured in the laboratory. Molecular approaches based on nucleotide sequence analysis have characterized the full diversity of dental plaque [Kroes et al., 1999; Wade, 1999; Paster et al., 2001] and identified a large number of novel taxa [Dewhirst et al., 2000]. Improvements in the taxonomy of plaque isolates based on, for example, the unique DNA sequences of the $16 \mathrm{~S}$ subunit rRNA (16S rDNA) gene

$\overline{206} \quad \overline{\text { Caries Res 2004;38:204-211 }}$ 
have resulted in the more valid subdivision of existing species. This can also lead to the finer resolution of species into biovars, genotypes or other subgroups, which facilitates better epidemiological studies [Redmo-Emanuelsson et al., 2003] and the possibility of the closer correlation of particular clonal types with disease, as has occurred with Actinobacillus actinomycetemcomitans and early-onset periodontitis [Haubek et al., 2001]. These unique sequences can be used as templates for nucleotide probes which, when coupled with a reporter system and used in conjunction with confocal microscopy, can visualize and quantify individual species in natural biofilms, e.g. by fluorescent in situ hybridization [Thurnheer et al., 2001; Kolenbrander et al., 2002]. Pilot studies of plaque developing on removable materials in deep periodontal pockets showed that the deepest zones were colonized mainly by spirochaetes and gram-negative bacteria, whereas shallow regions comprised predominantly grampositive cocci [Wecke et al., 2000]. These and similar approaches will enable a more complete description of the plaque microflora in health and disease, and also provide data on the location of, and structural interrelationships among, target species in the biofilm [Thurnheer et al., 2001; Kolenbrander et al., 2002]. The recent application of molecular methods to infected dentine has resulted in the detection and identification of previously uncultured bacteria [Munson et al., 2003].

\section{Biofilm Regulation of Gene Expression}

Bacteria in biofilms display a phenotype that is distinct from that exhibited by the same cells growing planktonically. The binding of bacteria to specific receptors can trigger significant changes in both bacterial and host cell patterns of gene expression, e.g. following the initial attachment of Escherichia coli to uro-epithelial cells [Abraham et al., 1998]. Similarly, there is up-regulation of genes involved with alginate synthesis when Pseudomonas aeruginosa colonizes a surface [Boyd and Chakrabarty, 1995].

Similar surface-associated responses are now being identified in plaque bacteria, although the magnitude of this shift in gene expression may be less than that observed in free-living species because of the absolute dependence of oral bacteria on a biofilm lifestyle [Burne, 1998]. The exposure of Streptococcus gordonii to saliva resulted in the induction of genes $(s s p A / B)$ encoding adhesins that can bind to salivary glycoproteins and engage in co-aggregation with Actinomyces spp. [Du and Kolenbrander, 2000], implying similar changes may occur during colonization. Changes in protein profile fol- lowing attachment have been identified in Streptococcus mutans using a whole-cell proteomic approach [Svensater et al., 2001]. Proteins involved in a range of biochemical functions including protein folding and secretion, amino acid and fatty acid biosynthesis, and cell division were up-regulated. Of particular significance, novel proteins of as yet unknown function were expressed by biofilm but not planktonic cells. Similarly, genes associated with glucan $(g t f B C)$ and fructan synthesis $(f t f)$ in $S$. mutans were differentially regulated in biofilms [Li and Burne, 2001]. There was little influence of surface growth in early biofilm formation $(<48 \mathrm{~h})$, but $g t f$ expression was markedly up-regulated in older (7-day) biofilms, whereas $f t f$ activity was repressed. This was interpreted as an indirect effect of biofilm growth on gene expression, i.e. the altered phenotype was probably due to changes in local environmental conditions within the biofilm (e.g. sugar concentration, $\mathrm{pH})$ rather than due to attachment per se [Li and Burne, 2001]. Thus, biofilm growth can have both direct and indirect influences on gene expression by oral bacteria.

\section{Cell-Cell Communication}

In addition to the conventional biochemical and metabolic interactions that have been well catalogued, cells have also been shown to communicate with one another in biofilm communities via small diffusible molecules. Many bacterial species have evolved cell-cell signalling systems (quorum sensing) that help them to adapt and survive various environmental stresses in a cell-densitydependent manner and regulate the expression of genes that also influence their ability to cause disease. In $S$. mutans, quorum sensing is mediated by a competencestimulating peptide (CSP) [Li et al., 2002b]. This peptide also induced genetic competence in $S$. mutans so that the transformation frequency of biofilm-grown $S$. mutans was 10- to 600-fold greater than for planktonic cells [Li et al., 2001]. Lysed cells in biofilms could act as donors of chromosomal DNA, thereby increasing the opportunity for horizontal gene transfer in dental plaque. CSP is also directly involved in biofilm formation; mutants in some of the genes involved in the CSP signalling system $(\operatorname{com} C$, comD, comE and $\operatorname{com} X$ ) produce defective biofilms [Li et al., 2002b]. This quorum sensing system also functions to regulate acid tolerance in $S$. mutans biofilms [ $\mathrm{Li}$ et al., 2002a]. It has been proposed that $S$. mutans, upon exposure to low $\mathrm{pH}$, could release CSP and initiate a co-ordinated 'protective' response among neighbouring cells to such a potentially lethal stress. CSPs are specific for cells of the same species, but other communication systems may function between different taxa [Kolenbrander et al., 
2002]. Genes encoding autoinducer 2 have been detected in several genera of gram-positive and gram-negative bacteria so that autoinducer 2 may have a broader species range, although its role in plaque remains to be determined. However, mutants of the luxS gene that encodes for the autoinducer 2 synthase in $S$. mutans and $S$. gordonii had an impaired ability to produce monospecies biofilms in vitro [Blehert et al., 2003; Merritt et al., 2003].

Future research will identify more of these sophisticated communication networks, and it has been suggested that analogues of the signalling molecules could be used as novel therapeutic agents to manipulate the properties of biofilms.

\section{Gene Transfer}

Cells also communicate with one another in biofilms via horizontal gene transfer. As discussed above, signalling molecules such as CSP markedly increase the ability of recipient cells in biofilms to take up DNA [Li et al., 2002b]. The transfer of conjugative transposons encoding tetracycline resistance between streptococci in model biofilms has been demonstrated [Roberts et al., 2001]. The recovery of resident (S. mitis, $S$. oralis) and pathogenic $(S$. pneumoniae) bacteria from the nasopharynx with penicillin resistance genes showing a common mosaic structure confirms that gene transfer can occur in vivo [Dowson et al., 1990; Hakenbeck et al., 1998]. Similar evidence suggests sharing of genes responsible for penicillin-binding proteins among commensal and pathogenic Neisseria [Bowler et al., 1994]. These findings suggest that plaque can function as a 'genotypic reservoir' by harbouring transferable mobile elements and genes. Such genetic exchange could have a wider significance given the number of overtly pathogenic bacteria that appear transiently in the mouth [Loo, 2003].

\section{Antimicrobial Resistance}

A major finding of clinical relevance with respect to micro-organisms growing on a surface is their increased resistance to antimicrobial agents [Gilbert et al., 1997, 2002; Ceri et al., 1999]. For example, $P$. aeruginosa growing on urinary catheter material can be 500-1,000 times more resistant to antibiotics than the same cells growing in liquid culture. Conventionally, the sensitivity of bacteria to antimicrobial agents is determined on cells grown in liquid culture by the measurement of the minimum inhibitory concentration or minimum bactericidal concentration. Given the decreased sensitivity of an organism on a surface, it has been argued that it would be more appro- priate to determine the 'biofilm inhibitory concentration' (also described as the 'biofilm eradicating concentration' or biofilm killing concentration) [Anwar et al., 1990; Nichols, 1994; Shani et al., 2000; Johnson et al., 2002]. As yet, however, these proposals have not been widely accepted, and there are no generally agreed standardized methods by which these concentrations could be determined.

Bacteria growing in dental plaque also display increased resistance to antimicrobial agents, including those used in dentifrices and mouth rinses [Marsh and Bradshaw, 1993; Kinniment et al., 1996; Wilson, 1996; Pratten and Wilson, 1999]. For example, the biofilm inhibitory concentration for chlorhexidine and amine fluoride was 300 and 75 times greater, respectively, when $S$. sobrinus was grown as a biofilm compared with the minimum bactericidal concentration of planktonic cells [Shani et al., 2000]. Similarly, it was necessary to administer 1050 times the minimum inhibitory concentration of chlorhexidine to eliminate $S$. sanguinis (previously $S$. sanguis) biofilms within $24 \mathrm{~h}$ [Larsen and Fiehn, 1996]. The age of the biofilm can also be a significant factor; older biofilms (72 h) of S. sanguinis were more resistant to chlorhexidine than younger $(24 \mathrm{~h})$ biofilms [Millward and Wilson, 1989]. Confocal microscopy of in situ established natural biofilms showed that chlorhexidine only affected the outer layers of cells in 24- and 48-hour plaque biofilms [Zaura-Arite et al., 2001]. Biofilms of oral bacteria are also more resistant to antibiotics (e.g. amoxycillin, doxycycline, metronidazole) [Larsen, 2002; Larsen and Fiehn, 1996].

The mechanisms behind the increased resistance of biofilms to antimicrobial agents are the subject of much research and debate [Gilbert et al., 2002]. Cells can become resistant due to mutations affecting the drug target, the presence of efflux pumps or to the production of modifying enzymes etc., but even innately sensitive bacteria become resistant when growing on a surface. The structure of a biofilm may restrict the penetration of the antimicrobial agent; some charged inhibitors can bind to oppositely charged polymers that make up the biofilm matrix (diffusion-reaction theory). The agent may also bind to and inhibit the organisms at the surface of the biofilm, leaving cells in the depths of the biofilm relatively unaffected. As stated earlier, bacteria growing on a surface display a novel phenotype, and this can result in a reduced sensitivity to inhibitors, while the transfer of resistance genes can occur more readily in biofilm communities such as dental plaque. Growth on a surface may also result in the drug target being modified or not expressed in a 
biofilm, or the organism may use alternative metabolic strategies. Bacteria grow only slowly under nutrientdepleted conditions in an established biofilm and, as a consequence, are much less susceptible than faster-dividing cells. In addition, it has also been proposed that the environment in the depths of a biofilm may be unfavourable for the optimal action of some drugs [Gilbert et al., 2002]. The matrix in biofilms can also bind and retain neutralizing enzymes ( $\beta$-lactamase, IgA protease; see above) [Allison, 2003]. At present, it is not clear whether some or all of these effects account for the observed resistance of cells in plaque biofilms.

\section{Plaque as a Community}

The evidence outlined above on the ability of plaque bacteria to interact with neighbouring cells in biofilms provides compelling support for the concept that oral bacteria do not exist as independent entities but rather function as a co-ordinated, spatially organized and metabolically integrated microbial community [Marsh and Bradshaw, 1999]. Benefits of a community lifestyle to micro-organisms include: (a) a broader habitat range for growth, e.g. oxygen-consuming species create environmental conditions suitable for obligate anaerobes; (b) a more efficient metabolism, e.g. complex host macromolecules can only be degraded by consortia of oral bacteria; (c) increased resistance to stress and antimicrobial agents, and (d) enhanced virulence ('pathogenic synergism') [Caldwell et al., 1997; Shapiro, 1998; Marsh and Bowden, 2000] (table 1). Microbial community effects can render a sensitive organism as apparently 'resistant' to an antibiotic if neighbouring, non-pathogenic cells produce a neutralizing or drug-degrading enzyme ('indirect pathogenicity'). This has been demonstrated in animal models where a penicillin-sensitive pathogen (S. pyogenes) is protected by a $\beta$-lactamase-producing commensal strain (Moraxella catarrhalis) and, as a result, is still capable of causing a lethal infection [Hol et al., 1994]. In the mouth, gingival crevicular fluid can contain sufficient $\beta$-lactamase to inactivate the concentrations of antibiotic delivered to the site [Walker et al., 1987; Herrera et al., 2000].

\section{Future Developments}

A greater understanding of the significance of dental plaque as a mixed species biofilm will have the potential to impact significantly on clinical practice. Novel areas for future research include: (a) the development of inhibitors and antiplaque agents that are more effective against surface-associated micro-organisms, coupled with more effective delivery systems for targeting specific bacteria and for improving the retention of agents in the mouth; this will require the development and use of high throughput biofilm models to screen novel compounds not only for their ability to kill or inhibit sessile cells, but also to promote biofilm detachment;

(b) interference with communication networks that coordinate or regulate microbial activities within biofilms; in other areas of microbiology (e.g. P. aeruginosa and cystic fibrosis), attempts are being made to block signalling molecules that induce a shift in the host to a more virulent phenotype;

(c) preventing colonization of selected organisms (e.g. by interfering with attachment by modifying the conditioning film or by 'replacement therapy', whereby organisms are deliberately implanted to prevent subsequent colonization by more pathogenic species) [Hillman, 1999; Tagg and Dierksen, 2003];

(d) affecting biofilm architecture, for example, by the use of enzymes that can degrade the exopolymers that comprise the plaque matrix;

(e) the neutralization of parameters that select for the species that are implicated in disease [Marsh, 2003]; thus, strategies that reduce the $\mathrm{pH}$ response to dietary carbohydrates will help prevent the enrichment of acidogenic and aciduric bacteria;

(f) the identification of pathogenic clones could also improve diagnosis and might predict sites that are more susceptible to disease. 


\section{References}

Abraham SN, Jonsson A-B, Normark S: Fimbriaemediated host pathogen cross-talk. Curr Opin Microbiol 1998;1:75-81.

Al-Hashimi I, Levine MJ: Characterization of in vivo saliva-derived enamel pellicle. Arch Oral Biol 1989;34:289-295.

Allison D, Gilbert P, Lappin-Scott HM, Wilson M: Community Structure and Co-Operation in Biofilms. Society for General Microbiology Symposium 59. Cambridge, Cambridge University Press, 2000.

Allison DG: The biofilm matrix. Biofouling 2003; 19:139-150.

Anwar H, Dasgupta MK, Costerton JW: Testing the susceptibility of bacteria in biofilms to antibacterial agents. Antimicrob Agents Chemother 1990;34:2043-2046.

Auschill TM, Arweiler NB, Netuschil L, Brecx M, Reich E, Sculean A: Spatial distribution of vital and dead microorganisms in dental biofilms. Arch Oral Biol 2001;46:471-476.

Beighton D, Smith K, Hayday H: The growth of bacteria and the production of exoglycosidic enzymes in the dental plaque of macaque monkeys. Arch Oral Biol 1986;31:829-835.

Blehert DS, Palmer RJ Jr, Xavier JB, Almeida JS, Kolenbrander P: Autoinducer 2 production by Streptococcus gordonii DL1 and the biofilm phenotype of a luxS mutant are influenced by nutritional conditions. J Bacteriol 2003;185: 4851-4860

Bowden GH, Hardie JM, Slack GL: Microbial variations in approximal dental plaque. Caries Res 1975;9:253-277.

Bowler LD, Zhang Q-Y, Riou J-Y, Spratt BG: Interspecies recombination between the pen $A$ genes of Neisseria meningitidis and commensa Neisseria species during the emergence of penicillin resistance in $N$. meningitidis: Natural events and laboratory simulation. J Bacteriol 1994;176:333-337.

Boyd A, Chakrabarty AM: Pseudomonas aeruginosa biofilms: Role of the alginate exopolysaccharide. J Ind Microbiol 1995;15:162-168.

Bradshaw DJ, Homer KA, Marsh PD, Beighton D Metabolic cooperation in oral microbial communities during growth on mucin. Microbiology $1994 ; 140: 3407-3412$

Bradshaw DJ, Marsh PD, Watson GK, Allison C: Role of Fusobacterium nucleatum and coaggregation in anaerobe survival in planktonic and biofilm oral microbial communities during aeration. Infect Immun 1998;66:4729-4732.

Burne RA: Regulation of gene expression in adherent populations of oral streptococci; in LeBlanc DJ, Lantz MS, Switalski LM (eds): Microbial Pathogenesis: Current and Emerging Issues. Indianapolis, Indiana University, 1998, pp 4153.

Busscher HJ, van der Mei HC: Physico-chemical interactions in initial microbial adhesion and relevance for biofilm formation. Adv Dent Res 1997;11:24-32.
Caldwell DE, Wolfaardt GM, Korber DR, Lawrence JR: Do bacterial communities transcend Darwinism? in Jones JG (ed): Advances in Microbial Ecology. New York, Plenum Press, 1997, vol 15, pp 105-191.

Cavedon K, London J: Adhesin degradation: A possible function for a Prevotella loescheii protease? Oral Microbiol Immunol 1993;8:283287.

Ceri H, Olson ME, Stremick C, Read RR, Morck D, Buret A: The Calgary biofilm device: New technology for rapid determination of antibiotic susceptibilities of bacterial biofilms. J Clin Microbiol 1999;37:1771-1776.

Dewhirst FE, Tamer MA, Ericson RE, Lau CN, Levanos VA, Boches SK, Galvin JL, Paster BJ: The diversity of periodontal spirochetes by $16 \mathrm{~S}$ rRNA analysis. Oral Microbiol Immunol 2000; 15:196-202.

Dowson CG, Hutchison A, Woodford N, Johnson AP, George RC, Spratt BG: Penicillin-resistant viridans streptococci have obtained altered penicillin-binding protein genes from penicillin-resistant strains of Streptococcus pneumoniae. Proc Natl Acad Sci USA 1990;87:58585862.

Du LD, Kolenbrander PE: Identification of salivaregulated genes of Streptococcus gordonii DL1 by differential display using random arbitrarily primed PCR. Infect Immun 2000;68:48344837.

Gelle MP, Jacquelin LF, Choisy C: Compare viability of planctonic bacteria and bacteria in biofilms by flow cytometry. Ann Pharm Fr 2003; 61:243-252.

Gilbert P, Das J, Foley I: Biofilm susceptibility to antimicrobials. Adv Dent Res 1997;11:160167.

Gilbert P, Maira-Litran T, McBain AJ, Rickard $\mathrm{AH}$, Whyte FW: The physiology and collective recalcitrance of microbial biofilm communities. Adv Microb Physiol 2002;46:203-255.

Hakenbeck R, Konog A, Kern I, van der Linden M, Keck W, Billot-Klein D, Legrand R, Schoot B, Gutmann L: Acquisition of five high-Mr penicillin-binding protein variants during transfer of high-level beta-lactam resistance from Streptococcus mitis to Streptococcus pneumoniae. J Bacteriol 1998;180:1831-1840.

Haubek D, Ennibi OK, Poulsen K, Poulsen S, Benzarti N, Kilian M: Early-onset periodontitis in Morocco is associated with the highly leukotoxic clone of Actinobacillus actinomycetemcomitans. J Dent Res 2001;80:1580-1583.

Herrera D, van Winkelhoff AJ, Dellemijn-Kippuw N, Winkel EG, Sanz M: Beta-lactamase producing bacteria in the subgingival microflora of adult patients with periodontitis: A comparison between Spain and the Netherlands. J Clin Periodontol 2000;27:520-525.

Hillman JD: Replacement therapy of dental caries; in Newman HN, Wilson M (eds): Dental Plaque Revisited: Oral Biofilms in Health and Disease. Cardiff, BioLine, 1999, pp 587-599.
Hol C, van Dijke EEM, Verduin CM, Verhoef J, van Dijk H: Experimental evidence for Moraxella-induced penicillin neutralization in pneumococcal pneumonia. J Infect Dis 1994;170: 1613-1616.

Hope CK, Wilson M: Cell viability within oral biofilms; in McBain A, Allison D, Brading M, Rickard A, Verran J, Walker J (eds): Biofilm Communities: Order from Chaos? Cardiff, BioLine, 2003, pp 269-284.

Jenkinson HF, Lamont RJ: Streptococcal adhesion and colonization. Crit Rev Oral Biol Med 1997;8:175-200.

Johnson SA, Goddard PA, Iliffe C, Timmins B, Rickard AH, Robson G, Handley PS: Comparative susceptibility of resident and transient hand bacteria to para-chloro-meta-xylenol and triclosan. J Appl Microbiol 2002;93:336-344.

Kinniment SL, Wimpenny JWT, Adams D, Marsh PD: The effect of chlorhexidine on defined, mixed culture oral biofilms grown in a novel model system. J Appl Bacteriol 1996;81:120125.

Kolenbrander PE, Andersen RN, Blehert DS, Egland PG, Foster JS, Palmer RJ: Communication among oral bacteria. Microbiol Mol Biol Rev 2002;66:486-450.

Kolenbrander PE, Andersen RN, Kazmerak KM, Palmer RJ: Coaggregation and coadhesion in oral biofilms; in Allison DG, Gilbert P, Lappin-Scott HM, Wilson M (eds): Community Structure and Co-Operation in Biofilms. Society for General Microbiology Symposium 59. Cambridge, Cambridge University Press, 2000, pp 65-85.

Kopec LK, Vacca-Smith AM, Wunder D, NgEvans L, Bowen WH: Properties of Streptococcus sanguinis glucans formed under various conditions. Caries Res 2001;35:67-74.

Kroes I, Lepp PW, Relman DA: Bacterial diversity within the human subgingival crevice. Proc Natl Acad Sci USA 1999;96:14547-14552.

Lamont RJ, Jenkinson HF: Adhesion as an ecological determinant in the oral cavity; in Kuramitsu HK, Ellen RP (eds): Oral Bacterial Ecology: The Molecular Basis. Wymondham, Horizon Scientific Press, 2000, pp 131-168.

Larsen T: Susceptibility of Porphyromonas gingivalis in biofilms to amoxicillin, doxycycline and metronidazole. Oral Microbiol Immunol 2002;17:267-271.

Larsen T, Fiehn NE: Resistance of Streptococcus sanguis biofilms to antimicrobial agents. APMIS B 1996;104:280-284.

Lee SF, Li YH, Bowden GWH: Detachment of Streptococcus mutans biofilm cells by an endogenous enzyme activity. Infect Immun 1996; 64:1035-1038.

Li J, Helmerhorst EJ, Corley RB, Luus LE, Troxler LE, Oppenheim FG: Characterization of the immunologic responses to human in vivo acquired enamel pellicle as a novel means to investigate its composition. Oral Microbiol Immunol 2003;18:183-191. 
Li Y, Burne RA: Regulation of the $g t f B C$ and $f t f$ genes of Streptococcus mutans in biofilms in response to $\mathrm{pH}$ and carbohydrate. Microbiology 2001;147:2841-2848.

Li Y-H, Lau PCY, Lee JH, Ellen RP, Cvitkovitch DG: Natural genetic transformation of Streptococcus mutans growing in biofilms. Infect Immun 2001;183:897-908.

Li Y-H, Lau PCY, Tang N, Svensater G, Ellen RP, Cvitkovitch DG: Novel two-component regulatory system involved in biofilm formation and acid resistance in Streptococcus mutans. J Bacteriol 2002a; 184:6333-6342.

Li Y-H, Tang N, Aspiras MB, Lau PCY, Lee JH, Ellen RP, Cvitkovitch DG: A quorum-sensing signaling system essential for genetic competence in Streptococcus mutans is involved in biofilm formation. J Bacteriol 2002b;184: 2699-2708.

Listgarten M: Formation of dental plaque and other biofilms; in Newman HN, Wilson M, (eds): Dental Plaque Revisited: Oral Biofilms in Health and Disease. Cardiff, BioLine, 1999, pp 187-210.

Loo CY: Oral streptococcal genes that encode biofilm formation; in Wilson M, Devine DA (eds): Medical Implications of Biofilms. Cambridge Cambridge University Press, 2003, pp 189 211.

Marsh PD: Oral ecology and its impact on oral microbial diversity; in Kuramitsu HK, Ellen RP (eds): Oral Bacterial Ecology: The Molecular Basis. Wymondham, Horizon Scientific Press, 2000a, pp 11-65.

Marsh PD: Role of the oral microflora in health. Microb Ecol Health Dis 2000b;12:130-137.

Marsh PD: Are dental diseases examples of ecological catastrophes? Microbiology 2003;149:279_ 294.

Marsh PD, Bowden GHW: Microbial community interactions in biofilms; in Allison DG, Gilbert P, Lappin-Scott HM, Wilson M (eds): Community Structure and Co-Operation in Biofilms. Society for Microbiology Symposium 59. Cambridge, Cambridge University Press, 2000, pp 167-198.

Marsh PD, Bradshaw DJ: Microbiological effects of new agents in dentifrices for plaque control. Int Dent J 1993;43:399-406.

Marsh PD, Bradshaw DJ: Microbial community aspects of dental plaque; in Newman HN, Wilson M (eds): Dental Plaque Revisited: Oral Biofilms in Health and Disease. Cardiff, BioLine, 1999, pp 237-253.

Marsh PD, Nyvad B: The oral microflora and biofilms on teeth; in Fejerskov O, Kidd EAM, (eds): Dental Caries: The Disease and Its Clinical Management. Oxford, Blackwell, 2003, pp 29-48.
McFarland LV: Normal flora: Diversity and functions. Microb Ecol Health Dis 2000;12:193207.

Merritt J, Qi F, Goodman SD, Anderson MH, Shi $\mathrm{W}$ : Mutation of $\operatorname{luxS}$ affects biofilm formation in Streptococcus mutans. Infect Immun 2003; 71:1972-1979.

Millward TA, Wilson M: The effect of chlorhexidine on Streptococcus sanguis biofilms. Microbios 1989;58:155-164.

Munson MA, Banerjee A, Watson TF, Wade WG: Molecular analysis of the microflora associated with dentinal caries (abstract). Caries Res 2003;37:297.

Newman HN, Wilson M (eds): Dental Plaque Revisited: Oral Biofilms in Health and Disease. Cardiff, BioLine, 1999.

Nichols WW: Biofilm permeability to antibacterial agents; in Wimpenny J, Nichols W, Stickler D, Lappin-Scott H (eds): Bacterial Biofilms and Their Control in Medicine and Industry. Cardiff, BioLine, 1994, pp 141-149.

Nyvad B: Microbial colonization of human tooth surfaces. APMIS B 1993;101:7-45.

Paster BJ, Bosches SK, Galvin JL, Ericson RE, Lau CN, Levanos VA, Sahasrabudhe A, Dewhirst FE: Bacterial diversity in human subgingival plaque. J Bacteriol 2001;183:3770-3783.

Percival RS, Challacombe SJ, Marsh PD: Agerelated microbiological changes in the salivary and plaque microflora of healthy adults. J Med Microbiol 1991;35:5-11.

Pratten J, Wilson M: Antimicrobial susceptibility and composition of microcosm dental plaques supplemented with sucrose. Antimicrob Agents Chemother 1999;43:1595-1599.

Redmo-Emanuelsson IM, Carlsson P, Hamberg K, Bratthall D: Tracing genotypes of mutans streptococci on tooth sites by random amplified polymorphic DNA (RAPD) analysis. Oral Microbiol Immunol 2003; 18:24-29.

Roberts AP, Cheah G, Ready D, Pratten J, Wilson M, Mullany P: Transfer of TN916-like elements in microcosm dental plaques. Antimicrob Agents Chemother 2001;45:2943-2946.

Robinson C, Kirkham J, Percival R, Shore RC, Bonass WA, Brookes SJ, Kusa L, Nakagaki H, Kato K, Nattress B: A method for the quantitative site-specific study of the biochemistry within dental plaque biofilms formed in vivo. Caries Res 1997;31:194-200.

Shani S, Friedman M, Steinberg D: The anticariogenic effect of amine fluorides on Streptococcus sobrinus and glucosyltransferase in biofilms. Caries Res 2000;34:260-267.

Shapiro JA: Thinking about bacterial populations as multicellular organisms. Annu Rev Microbiol 1998;52:81-104.
Slots J: Microflora in the healthy gingival sulcus in man. Scand J Dent Res 1977;85:247-254.

Svensater G, Welin J, Wilkins JC, Beighton D, Hamilton IR: Protein expression by planktonic and biofilm cells of Streptococcus mutans. FEMS Microbiol Lett 2001;205:139-146.

Tagg JR, Dierksen KP: Bacterial replacement therapy: Adapting 'germ warfare' to infection prevention. Trends Biotechnol 2003;21:217-223.

Theilade E, Fejerskov O, Karring T, Theilade J: Predominant cultivable microflora of human dental fissure plaque. Infect Immun 1982;36: 977-982.

Thurnheer T, Gmur R, Giertsen E, Guggenheim B: Automated fluorescent in situ hybridization for the specific detection and quantification of oral streptococci in dental plaque. J Microbiol Methods 2001;44:39-47.

Thurnheer T, Gmur R, Shapiro S, Guggenheim B Mass transport of macromolecules within an in vitro model of supragingival plaque. Appl Environ Microbiol 2003;69:1702-1709.

Vacca-Smith AM, Venkitaraman AR, Schilling KM, Bowen WH: Characterization of glucosyltransferase of human saliva adsorbed onto hydroxyapatite surfaces. Caries Res 1996;30: 354-360.

Vroom JM, de Grauw KJ, Gerritsen HC, Bradshaw DJ, Marsh PD, Watson GK, Allison C, Birmingham JJ: Depth penetration and detection of $\mathrm{pH}$ gradients in biofilms using two-photon excitation microscopy. Appl Environ Microbiol 1999;65:3502-3511.

Wade W: Unculturable bacteria in oral biofilms; in Newman HN, Wilson M (eds): Dental Plaque Revisited: Oral Biofilms in Health and Disease. Cardiff, BioLine, 1999, pp 313-322.

Walker CB, Tyler KT, Low SB, King CJ: Penicillindegrading enzymes in sites associated with adult periodontitis. Oral Microbiol Immunol 1987;2:129-131.

Wecke J, Kersten T, Madela K, Moter A, Gobel UB, Friedmannn A, Bernimoulin J: A novel technique for monitoring the development of bacterial biofilms in human periodontal pockets. FEMS Microbiol Lett 2000;191:95-101.

Wilson M: Susceptibility of oral bacterial biofilms to antimicrobial agents. J Med Microbiol 1996; 44:79-87.

Wood SR, Kirkham J, Marsh PD, Shore RC, Nattress B, Robinson C: Architecture of intact natural human plaque biofilms studied by confocal laser scanning microscopy. J Dent Res 2000;79:21-27.

Zaura-Arite E, van Marle J, ten Cate JM: Confocal microscopy study of undisturbed and chlorhexidine-treated dental biofilm. J Dent Res 2001; 80:1436-1440. 